\title{
THE LIMITATIONS OF MICROCREDIT FOR PROMOTING MICROENTERPRISES IN BANGLADESH
}

\author{
Md. Mahmudul Alam \\ Institute for Environment and Development (LESTARI), National University of \\ Malaysia (UKM), Selangor, Malaysia, rony000@gmail.com

\section{Rafiqul Islam Molla} \\ Faculty of Business and Law, Multimedia University, Melaka, Malaysia, \\ rimolla@gmail.com
}

\section{Citation Reference:}

Alam, M.M., and Molla, R.I. 2012. The Limitations of Microcredit for Promoting Microenterprises in Bangladesh, Economic Annals, Vol. 57(192), pp. 41-53, DOI: 10.2298/EKA1292041A. Available at < http://ea.ekof.bg.ac.rs/pdf/192/138.pdf > (ISSN: 0013-3264; Publisher- University of Belgrade, Servia)

This is a pre-publication copy.

The published article is copyrighted by the publisher of the journal. 


\title{
THE LIMITATIONS OF MICROCREDIT FOR PROMOTING MICROENTERPRISES IN BANGLADESH
}

\author{
Md. Mahmudul Alam* , Rafiqul Islam Molla**
}

\begin{abstract}
Microcredit is regarded as a tool for poverty alleviation. A stereotyped delivery system is designed and used for promoting and serving survival- and subsistencelevel economic activities, particularly for poor female clients. In Bangladesh its success has raised social expectations as to its potential as also a promoter of microenterprises, which are growth-yielding small businesses beyond subsistencelevel economic activity. The field survey shows that about $11.7 \%$ of the microcredit borrowers are this kind of potential or growing microentrepreneur. It also shows that microcredit's standardised delivery system, particularly in respect of gender preference, loan size, loan disbursement, and repayment schedules, is a strong limiting factor in effectively serving the microenterprises, which require a more flexible credit package. Therefore a methodological modification is necessary to accommodate flexibility in the microcredit delivery system.
\end{abstract}

Key words: Grameen Bank, microcredit, microenterprise, subsistence, poverty alleviation, stereotype

JEL Classification: O12, O29

\section{Introduction}

Microcredit deals with very small-scale financial services, for example, savings and loans for non-productive purposes such as emergencies and day-to-day living, and for productive purposes such as investment in productive activities. Credit is provided to groups of individuals or to village organizations without any collateral. It is usually delivered in a scheme of joint-liability use (peer pressure) to enforce loan repayment. It is considered to be a tool for poverty alleviation in

\footnotetext{
* Institute for Environment and Development (LESTARI), National University of Malaysia (UKM), Selangor, Malaysia, rony000@gmail.com

${ }^{* *}$ Faculty of Business and Law, Multimedia University, Melaka, Malaysia, rimolla@gmail.com
} 
developing countries. Prof. M. Yunus promoted a microcredit programme in Bangladesh under the name Grameen Bank, as an effective tool for enhancing the income of the poor through the creation of self-employment in various informal activities (Grameen Bank, 2009). Although the loans are made at very high interest rates, it has nonetheless provided the poor with access to the necessary credit to establish economic enterprises based on their existing skills, so that they can earn better income.

Bangladesh is called the land of microcredit. It is known for its high grow rate of microcredit borrowers. It has a total of 21.77 million borrowers, or 15.55 million effective borrowers after adjustment for multiple credits (PKSF, 2006). Microcredit is delivered typically through non-government organizations (NGOs) at exorbitantly high interest rates ranging from 25\%-65\% (Third Sector, 2004), whereas they obtain the bulk of their loans from the Bangladesh Bank at 4\%-5\% interest rate, and from their international donors at even lower rates. It should be also noted that the normal banking sector charges only $10 \%$ to $12 \%$ for loans to small and cottage industries (Bangladesh Bank, 1997).

Different studies have produced mixed results on the achievements and effectiveness of the microcredit delivery system in Bangladesh. The operating microcredit scheme is primarily meant and structured for promoting and supporting survival and subsistence economic enterprises. In this way it is a strategy for poverty alleviation and welfare promotion. But initially, decades ago, it was thought of and promoted as a growth-yielding tool in the pursuit of rural development. Because of its current international support and popularity many intellectuals, development agencies, social and political leaders, and microcredit delivery institutions in Bangladesh have started rethinking its scope as a potential tool for economic growth. Accordingly, many development agencies and microcredit institutions in the country are aspiring to include projects for the promotion and development of 'microeconomic enterprises' with the help of microcredit services. These enterprises are business, like operations, yet small and simple in structure such that they can be managed by the borrower and/or hired labour. These are beyond subsistence operations. Therefore, it is feared that the methodology of a stereotyped microcredit delivery system meant for 'survival and subsistent economic activities' is deficient in serving and supporting microenterprises ('micro economic enterprises').

Using the field data obtained from a survey of 555 selected sample microcredit borrowers from all over Bangladesh, from the authors' research project: Inside Story of Microcredit in Bangladesh - An Empirical Investigation on its Role and Productivity (Alam and Molla, 2011), this paper analyses the various limitations of the existing stereotyped microcredit delivery system in terms of its applicability 
in promoting microeconomic enterprises. The raw data of the survey were processed and analysed in the Working Paper \# 2/2010 (Molla, 2010). Data were collected during January-April, 2008. Samples were selected from urban (32.4\%), semi-urban $(27.2 \%)$, and rural $(40.4 \%)$ areas, to ensure that microborrowers of different sized loans engaged in various categories of economic operations in rural and urban settings were adequately represented. In the absence of full knowledge of the structure and distribution of the microcredit borrower population in the country, random sampling as representative sampling is neither possible nor desirable (Molla and Alam, 2011). Moreover, in many situations random sampling is neither effective nor cost effective in serving the purpose for which sample data are collected. Purposive or judgment sampling is effectively used in such cases. Accordingly, a judgment sampling procedure was thought more effective and appropriate for this survey. Since most microcredit institutions in the country closely follow the methodology of Grameen Bank's microcredit delivery system the analysis is made based on this system. The Grameen Bank model of microcredit is popularly known as Grameen microcredit.

\section{Microenterprises}

There are many variations in the definition of microenterprise. In this study it is defined as microcredit-invested economic activity where the investors are doing work that is beyond self-employment for sustenance. This may mean work by the borrower and/or hired labour, or a person doing skilled or professional work for self-employment and self-establishment but not for family sustenance. The economic activities of 65 , or $11.7 \%$, of the 555 sample microcredit borrowers fall into this category, as microenterprise or potentially microenterprise activities.

\section{Stereotyped Microcredit Delivery System}

As a collateral-free credit to small borrowers, microcredit is a detailed operation at high delivery cost. As a for-profit institution it provides services at a high price (interest rate) to cover the high cost and generate profit. It considers women as the more self-sacrificing and dedicated heads of the family and the more trustworthy users of the credit in income-generating activities for the family. It relies on developing the skills of the borrowers through informal training and education to transform them as human capital. It believes that regular saving by the borrowers is the ultimate solution to their economic problems. Accordingly, the delivery system has a built-in induced monthly savings scheme for the borrowers at $6 \%$ $12 \%$ interest rate. However, while $63.6 \%$ of borrowers reported that they knew of some return on their savings, $27.7 \%$ were not aware of any return/benefit. Proper use and timely repayment of the loan, and making monthly savings, are dependent on close supervision and group pressure. The amount of the loan for each 
borrower may vary only to an extent, and the entire amount is delivered at one time. Repayment of the loan starts with the first instalment due on the second week of the delivery of the loan; it assumes that investments in all activities are capable of generating return within a week. For simplicity, ease of supervision, and management control it relies on a standardized credit delivery system for all borrowers and for all economic activities.

\section{Limitations of the System for Promoting Micro Economic Enterprises}

The microcredit delivery system is structured to help poor borrowers (women) to create self-employment through subsistent economic activities according to their individual survival skills. Survey results suggest that, to the extent that the activities are only at survival and subsistence level, this standardized system is generally working. However, since individual survival skills are different for different borrowers who are pursuing different activities with different requirements for credit support, this stereotyped system may not be so effective for all borrowers. This is particularly true for the microeconomic enterprises which are beyond subsistent business operations, whose credit needs are different.. The standardized microcredit package suffers from a number of limitations in effectively serving and supporting microenterprises. These limitations have been observed and analysed in terms of gender preference, credit size, credit disbursement and repayment schedules, and interest rate charges.

\section{Gender Preferences}

About $97 \%$ of the borrowers in the survey are women. This is consistent with the results of previous studies and the annual reports of the microcredit providers. Microcredit providers prefer women as customers for microcredit due to the argument that in poor families women are the more self-sacrificing care-takers of the family, and are the more dependable and trustworthy users of the credit for the welfare of their families. This may be true and workable for economic activities at survival and subsistence levels of living. However, when there is a business-like economic activity women are not culturally and traditionally effective entrepreneurs and credit users in Bangladesh. Social customs and religious traditions do not encourage and respect women in business-like economic activities. As a result, in most cases the women collect the credit as borrowers (since the credit-providing institutions prefer to grant credit to women) but generally the male members of their families invest and use the fund (Goetz and Gupta, 1996). The survey found that in general only $10.6 \%$ of the women borrowers use the credit by themselves. In the remaining $89 \%$ of cases the male 
members of their families actually make the decisions and use the loan fund (Table 1).

Table 1. Users of Credit Borrowed by Women Clients (frequency)

\begin{tabular}{|l|r|r|}
\hline \multicolumn{1}{|c|}{ Loan User } & All Borrowers & Microenterprise Borrowers \\
\hline Self & $57(10.6 \%)$ & $6(9.5 \%)$ \\
\hline Male Family Members & $453(84.4 \%)$ & $56(88.9 \%)$ \\
\hline Third Party & $11(2.0 \%)$ & $1(1.6 \%)$ \\
\hline No Response & $16(3.0 \%)$ & 63 \\
\hline Total & 537 & \\
\hline $\begin{array}{l}* 18 \text { of the total 555 microcredit clients are male, and 2 of the 65 microcredit clients involved } \\
\text { in microenterprise are male. }\end{array}$
\end{tabular}

Source: Field Survey

A variety of reasons have been mentioned by the respondents (women borrowers) for their dependence on men for economic operations. The most frequently reported are: a) inability and lack of skill of the women borrowers, b) more investment opportunities in man-relevant activities, c) male-dominated family structure where male members maintain and control family, d) social environment and custom where business activities are considered to be men's work, and e) women are not expected or respected in the domain of men's activities (business activities). Therefore the preference for women as clients for credit is found to be a strong methodological limitation of the microcredit delivery system in promoting microenterprises.

\section{Standardized Credit Size, Disbursement and Repayment Schedules}

The size of the credit varies with the financing institution. In the Grameen Bank it varies within a fixed range from Tk 5,000 - 12,000 for each first-time borrower, irrespective of the nature of the economic operation. It is generally increased by a small amount each year on the basis of the borrower's amount of savings with the Bank, and not the credit needs of his/her economic operation. But different activities require different amounts of credit for effective operation. For many clients, more especially the microenterprise operators, this standardised scheme is grossly inadequate for their kind of business operation. Sharma (2002) observed that many borrowers found the credit amounts very inadequate as capital to initiate any reasonable business or to expand their existing businesses. In most cases, therefore, the borrowers have to find the required additional funding either 
from personal sources or from other microcredit providers. Many clients in the survey, particularly the microenterprise operators, borrowed concurrently from more than one credit institution.

About $63.9 \%$ of all the borrowers and only $33.9 \%$ of the microenterprise borrowers are found to have each invested an amount of Tk 20,000 or less in their business operations (Table 2). Similarly, $69.4 \%$ of all the borrowers and only $29.2 \%$ of the microenterprises feel that the required size of each loan should be Tk. 20,000 or less. This shows that, compared to the subsistence economic operations, the microenterprises require a larger amount of capital and therefore a larger loan to operate effectively.

Table 2. Borrowers' Investment Size and Desired Credit Size (frequency)

\begin{tabular}{|c|c|c|c|c|}
\hline \multirow{2}{*}{$\begin{array}{c}\text { Ranges of Amount } \\
\text { (Tk) }\end{array}$} & \multicolumn{2}{|c|}{ Investment Size* } & \multicolumn{2}{|c|}{ Desired Credit Size } \\
\hline & $\begin{array}{c}\text { All } \\
\text { Borrowers }\end{array}$ & $\begin{array}{c}\text { Microenterprise } \\
\text { Borrowers }\end{array}$ & $\begin{array}{c}\text { All } \\
\text { Borrowers }\end{array}$ & $\begin{array}{c}\text { Microenterprise } \\
\text { Borrowers }\end{array}$ \\
\hline $0^{\wedge}$ & $82(14.8 \%)$ & & & \\
\hline $0-5000$ & $61(11 \%)$ & $6(9.2 \%)$ & $17(3.1 \%)$ & $1(1.5 \%)$ \\
\hline $5001-10000$ & $152(27.4 \%)$ & $4(6.2 \%)$ & $131(23.6 \%)$ & $5(7.7 \%)$ \\
\hline $10001-15000$ & $89(16 \%)$ & $8(12.3 \%)$ & $81(14.6 \%)$ & $3(4.6 \%)$ \\
\hline $15001-20000$ & $53(9.5 \%)$ & $4(6.2 \%)$ & $156(28.1 \%)$ & $10(15.4 \%)$ \\
\hline $20001-25000$ & $31(5.6 \%)$ & $7(10.8 \%)$ & $18(3.2 \%)$ & $3(4.6 \%)$ \\
\hline $25001-30000$ & $25(4.5 \%)$ & $5(7.7 \%)$ & $32(5.8 \%)$ & $6(9.2 \%)$ \\
\hline $30001-35000$ & $11(2 \%)$ & $5(7.7 \%)$ & $1(0.2 \%)$ & \\
\hline $35001-40000$ & $11(2 \%)$ & $1(1.5 \%)$ & $6(1.1 \%)$ & $3(4.6 \%)$ \\
\hline $40001-45000$ & $6(1.1 \%)$ & $4(6.2 \%)$ & & \\
\hline $45001-50000$ & $8(1.4 \%)$ & $13(20 \%)$ & $50(9 \%)$ & $19(29.2 \%)$ \\
\hline $50000-100000$ & $17(3.1 \%)$ & $7(10.8 \%)$ & $18(3.2 \%)$ & $8(12.3 \%)$ \\
\hline $10000+$ & $9(1.6 \%)$ & $1(1.5 \%)$ & $11(2 \%)$ & $4(6.2 \%)$ \\
\hline
\end{tabular}




Not Sure
\begin{tabular}{lll} 
Total & $34(6.1 \%)$ & $3(4.6 \%)$ \\
\hline
\end{tabular}
$\wedge 1$ borrower who holds cash included in this category
$*$ Investment size is calculated as sum of microcredit loan investment, beginning personal
investment, and half of within-the-period personal investment. This is equivalent to full year
investment.

\section{Source: Field Survey}

As a standardised delivery method the entire amount of the granted loan is disbursed at one time to all clients, irrespective of the fact that for many types of activity the entire amount of the loan may not be required at the beginning of the operational cycle, for example, in agriculture and livestock activities. In these cases, a part of the loan received remains idle and is often used for unproductive purposes.

About $20.7 \%$ of all the borrowers and $15.4 \%$ of the microenterprise borrowers believe that they do not have the scope to effectively use the entire loan amount at the start of activities. In practice about $29.2 \%$ of all the borrowers and $20 \%$ of the microenterprise borrowers did not use the entire loan amount at the start of their business operations (Table 3). On the other hand, about $27.9 \%$ of all the borrowers and $55.4 \%$ of the microenterprise operators had to top-up the loan fund with personal or other borrowed funds to start operations. On top of that about $21.4 \%$ of all the borrowers and $8.6 \%$ of the microenterprise operators invested additional funds during the year, either from personal sources or from credits obtained from other microcredit providers. About $28.3 \%$ of all the sample clients and $40 \%$ of the microenterprise clients received multiple loans (2-3 or more) from 2-3 or more microcredit institutions.

\section{Table 3. Utilization of Microcredit and Structure of Borrowers' Investment (frequency)}

\begin{tabular}{|c|c|c|c|c|}
\hline \multirow{2}{*}{ Use of Credit Fund } & \multicolumn{2}{|c|}{$\begin{array}{c}\text { At Start } \\
\text { of the Operation }\end{array}$} & \multicolumn{2}{|c|}{$\begin{array}{c}\text { Additional Investment } \\
\text { during the Year* }\end{array}$} \\
\hline & $\begin{array}{c}\text { All } \\
\text { Borrowers }\end{array}$ & $\begin{array}{c}\text { Microenterprise } \\
\text { Borrowers }\end{array}$ & $\begin{array}{c}\text { All } \\
\text { Borrowers } \\
\end{array}$ & $\begin{array}{c}\text { Microenterpris } \\
\text { e Borrowers }\end{array}$ \\
\hline
\end{tabular}




\begin{tabular}{lcrrr} 
Investment- Part Amount & $162(29.2 \%)$ & $13(20 \%$ & $37(6.7 \%)$ & \\
$\begin{array}{l}\text { Investment- Full Amount } \\
\begin{array}{l}\text { Investment Full Credit } \\
\text { and Additional } \\
\text { Amounts }\end{array}\end{array}$ & $156(28.1 \%)$ & $16(24.6 \%)$ & $46(8.3 \%)$ & $2(3.4 \%)$ \\
\hline & & & & \\
Total & 555 & $65(55.4 \%)$ & $36(6.5 \%)$ & $3(5.2 \%)$ \\
\hline
\end{tabular}

* Additional amount for investment comes from personal and/or additional borrowing from other lending organizations

$\wedge 1$ borrower who holds cash included in this category

Source: Field Survey

\section{Starting Time for Credit Repayment}

It is assumed that most of the subsistence activities in which the microcredit borrowers are engaged are daily or weekly revenue-generating activities. The cycle of return on investment in such operations is very short. Accordingly, for all borrowers irrespective of type of economic operation in which the credits have been invested, the providers require the first instalment of the loan repayment to start from the week subsequent to the loan disbursement. In fact in many of these activities it is nearly impossible to get any significant return within a week of initiating the investment. For example, returns from investment in agriculture and livestock production may require months or years. As a result many of the borrowers have to pay the initial repayment instalments by arranging funds through another credit from other microcredit lending institutions or by selling their domestic animals, trees, etc. (Ahsan and Rahaman 2006). This is supported by the findings of this survey. About $30.8 \%$ of all the borrowers and $16.5 \%$ of the microenterprise operators are found to have invested the borrowed funds in fortnightly to yearly return-generating activities (Table 4). These borrowers face serious problems in finding money to follow the standardised repayment schedule.

Table 4. Cycle for Generation of Business Return from Microcredit Investment (frequency)

\begin{tabular}{lcc} 
Frequency of Return Generation & All Borrowers & Microenterprise Borrowers \\
\hline Daily & $322(61.9 \%)$ & $64(81 \%)$
\end{tabular}




\begin{tabular}{|c|c|c|}
\hline Weekly & $38(7.3 \%)$ & $2(2.5 \%)$ \\
\hline Fortnightly & $2(0.4 \%)$ & $1(1.3 \%)$ \\
\hline Monthly & $22(4 \%)$ & $4(5.1 \%)$ \\
\hline Quarterly & $10(1.8 \%)$ & $1(1.3 \%)$ \\
\hline Half Yearly & $62(11.2 \%)$ & $4(5.1 \%)$ \\
\hline Yearly & $64(11.5 \%)$ & $3(3.8 \%)$ \\
\hline Total & $520 *$ & $79^{\wedge}$ \\
\hline \multicolumn{3}{|c|}{$\begin{array}{l}\text { * Out of } 555 \text { sampled borrowers, } 47 \text { invested the borrowed funds in more than one activity, } \\
81 \text { did not invest but used the fund for consumption, and } 1 \text { was holding the cash in hand. That } \\
\text { is why the total activities of the } 555 \text { borrowers are } 520(555-82+47) \text {. }\end{array}$} \\
\hline
\end{tabular}

Source: Field Survey

\section{Uniform Interest Rate}

Micro Finance Institutions (MFIs) often claim that microcredit is highly productive at the subsistence level of economic activity but its delivery cost is very high because of the need for close and constant supervision and training for the borrowers. The loan providers therefore charge high interest rates to cover the high operating costs and generate sufficient profit/surplus. Different credit lenders charge interest at different rates, which vary from $25 \%-65 \%$. The interest rate is uniform for all microborrowers of a given credit-providing institution. The Grameen Bank charges nominal interest at $22.45 \%$, which is $30.5 \%$ effective interest rate because of weekly repayment instalments (Ahmad, 2007).

Obviously, the productivity of all borrowers and the profitability of all economic activities are not the same. However, microcredit lenders charge a uniform rate of interest for all borrowers. The Consultative Group to Assist the Poor (CGAP) observes that the borrowers deal with very low-return economic opportunities: therefore it is unreasonable to assume that they can pay such a high interest rate from the return on the investment (Todaro, 2006). The providers of microcredit to the rural poor are constantly and harshly criticised by economists, development activists, and politicians for charging exorbitantly high interest rates of $25 \%$ - 
$65 \%^{1}$. The present survey reveals that for $48.2 \%$ of all the borrowers and $26.1 \%$ of the microenterprise borrowers microcredit is not sufficiently productive to generate enough revenue for interest payments if market rate wages are paid for family labour. However, it is unproductive only for $7.6 \%$ of all the borrowers and $4.6 \%$ of the microenterprise borrowers if minimum wage is paid for family labour (Table 5). A previous study suggests that this exorbitantly high rate of interest charged by loan providers is in fact pushing borrowers to sell their labour at or below subsistence wage rate (Molla, Alam and Wahid, 2008).

Table 5. Interest Payment Capability from Microcredit Investment (frequency)

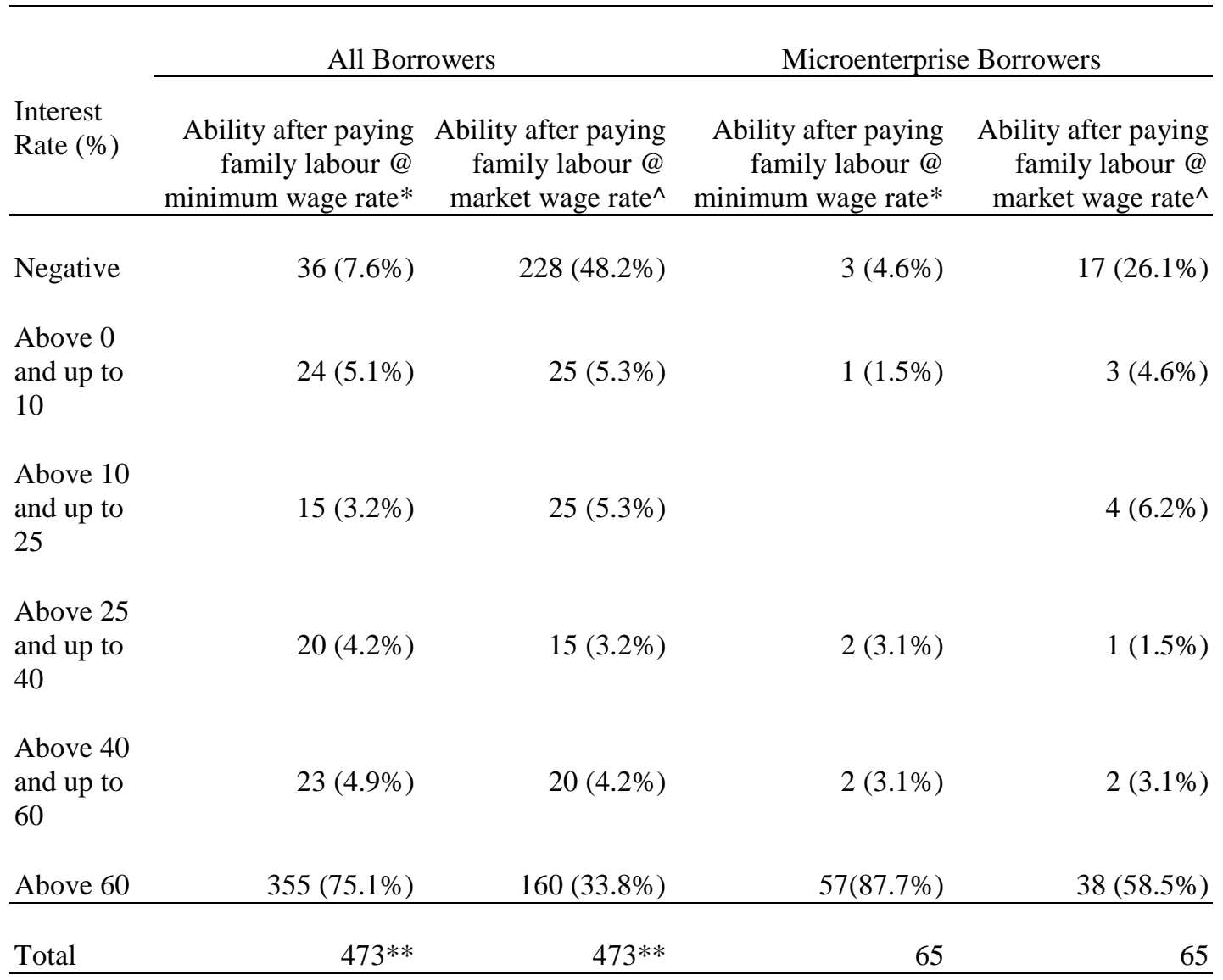

* Considering minimum labour rate @ tk 8 for male and Tk 5 for female, per hour.

^ Considering standard labour cost per hour at market rate= man @ tk 17.8, woman @ tk 12.4

\footnotetext{
${ }^{1}$ Consequently, the government of Bangladesh recently set $27 \%$ as the upper limit of chargeable interest rate on microcredit.
} 
** 1 person who was holding the credit fund in hand and the 81 non-investment cases are not included here

Source: Field Survey

\section{Need for Flexibility in the Delivery System}

To meet the growing expectations from various quarters for microcredit to be used as an effective growth-supporting tool in addition to its traditional use as a tool for poverty alleviation, its delivery system needs to be modified to make it fit to serve the specific nature of credit needs for microenterprises. A methodological accommodation has to be made to introduce more flexibility into the credit delivery system, at least in terms of gender preference, loan size, loan disbursement and repayment schedules, and interest rate charges. These should be allowed to vary according to the nature and size of the business and the natural cycle of return on investment. Microcredit must relax its attachment to and preference for female clients. In fact, especially in the context of Bangladeshi society, male entrepreneurs should be preferred in business-like enterprises. Grameen and other Bangladeshi microcredit institutions have recognized the need for a separate credit package for microenterprises. The Grameen Fund (2010) has undertaken a separate project to provide loans to microenterprises, but under very restricted conditions, which have turned it into almost a traditional commercial loan scheme. Most of the potential microenterprises are not able to enjoy the services and benefits of this loan programme. Therefore there is a need for a methodologically modified and more flexible microcredit scheme to effectively serve and promote microenterprises in Bangladesh.

\section{Conclusions}

The field survey found that over $11.7 \%$ of the microcredit borrowers are potential microenterprises, engaged in beyond survival- and subsistence-level economic operations. From the analyses of the field data it is evident that microcredit operates through a stereotyped delivery system which is meant to promote and serve survival and subsistent economic activities. As a result it suffers from methodological limitations in promoting and serving the potential microenterprises which are beyond subsistence-level activities. Because of its success and international respect there is a growing expectation and a rising social demand for microcredit to be used for promoting and serving microenterprises that are growth-generating small businesses and industrial operations. But microenterprises require a package of financial and credit services different from that for subsistent economic operations. Therefore there is a need for necessary 
methodological modifications to the existing stereotyped delivery system of microcredit in Bangladesh.

Microcredit has gained international respect and respect from its borrowers for its contribution to poverty alleviation and social empowerment for the poor. It is believed that with this high social respect it has the potential to also be successfully used as a growth-generating tool, particularly in the pursuit of rural development in Bangladesh.

\section{References}

Ahmad, Q.K. (ed.). (2007). Socio-Economic and Indebtedness-Related Impact of Micro-credit in Bangladesh. Dhaka: UPL Publications.

Ahsan, M. K., and Rahaman, M. Zillur. (2006). Recovery Rates of MicroCredit: A Study on Rural Women Participators. Journal of Business Studies, Southeast University. Vol. 2 (1).

Alam, M.M. and Molla, R.I. (2011). Inside Story of Microcredit in Bangladesh: An Empirical Investigation of the Role and Productivity, LAP Lambert Academic Publishing: Saarbrucken, Germany.

Bangladesh Bank. (1997). Inspection report on Grameen Bank. Conducted by the Department of Banking Inspection, Bangladesh Bank.

Geotz, A.M. and Gupta, R.S. (1996). Who takes the credit? Gender, power, and control over loan use in rural credit programs in Bangladesh. World Development, Vol. 24(1).

Grameen Bank. (2009). Grameen Bank at a glance. Annual Report 2008. Accessed December 20. Available at [http://www.grameen-info.org].

Grameen Fund. (2010). Micro-Enterprise Loan Scheme. Accessed February 2. Available at [http://www.grameen-info.org/grameen/gfund/micro.html]

Molla, R.I. (2010). Socioeconomic Productivity of Microcredit in Bangladesh: A Surgical Analysis, Working paper \# 2/2010, School on Local Development, University of Trento, Italy.

Molla, R.I., and Alam, M.M. (2011). Microcredit - A More Credible Social than Economic Institution in Bangladesh, Economics Bulletin, Vol. 31(2), pp. 
1095-1104. Accessed December 20. Available at [http://www.accessecon.com/Pubs/EB/2011/Volume31/EB-11-V31-I2P102.pdf].

Molla, R.I., Alam, M.M., and Wahid, A.N.M. (2008). Questioning Bangladesh's Microcredit. Challenge: The Magazine of Economic Affairs, Vol. 51(6), pp. 113- 121. Accessed December 20, 2011. Available at [http://econpapers.repec.org/article/meschalle/v_3a51_3ay_3a2008_3ai_3a 6_3ap_3a113-121.htm].

Palli Karma-Sahayak Foundation (PKSF). (2006). Maps on Microcredit Coverage in Upazilas of Bangladesh. Dhaka, Bangladesh.

Sharma, S. (2002). Is micro-credit a macro trap? The Hindu, 25, Sep. Accessed January 10, 2009. Available at [http://www.hinduonnet.com/businessline/2002/09/25/stories/20020925008 10900.htm].

Third Sector (Bengali Monthly Magazine). (2004). Specialist Abu Barakat's view of microcredit programmes run by NGOs. March, pp.24, Dhaka.

Todaro, M.P., and Smith, S.C. (2006). Economic Development. $9^{\text {th }}$ edition, pp.753, London: Pearson and Addison-Wesley. 